\title{
SISTEM AKUIFER DAN POTENSI AIRTANAH DAERAH ALIRAN SUNGAI (DAS) OPAK
}

\author{
Setyawan Purnama, Suyono, dan Budi Sulaswono \\ Fakultas Geografi, Universitas Gadjah Mada \\ Bulaksumur-Yogyakarta. Telp. 0272-902332/Fax. 0274-589595 \\ E-mail geografi@ugm.ac.id
}

\begin{abstract}
Cak. River Basin is an area with high concentration of settlement. Generally, the settlement use groundwater as a water source. Variation of groundwater condition cause differentiation of water usage in some regions.

There are two objectives of this research. First, to determine aquifer system in the research area and second, to calculate the groundwater potential in each aquifer system. To achieve these objectives, aquifer system is determined base on its geology and geomorphology, whereas groundwater potency is calculated by static and dynamic approach.

As a result, show that the aquifer system in Opak River Basin can be distinguished into seven aquifer system. There are The Upper Merapi Aquifer System, The Middle Merapi Aquifer System, The Lower Merapi Aquifer System, Baturagung Range Aquifer System, The Aquifer System of Baturagung Range Foot Slope, Sentolo Hill Aquifer System and Sanddune Aquifer System. Among the seventh aquifer system, The Middle Merapi Aquifer System, The Lower Merapi Aquifer System and The Sanddune Aquifer System have high productivity. Sentolo Hill Aquifer System and The Aquifer System of Baturagung Range Foot Slope Aquifer have low productivity, whereas The Baturagung Range is categorized as non akuifer.
\end{abstract}

Key words: aquifer system, groundwater

\section{PENDAHULUAN}

Sebagai sumberdaya alam, sumberdaya air mempunyai peranan yang sangat penting bagi kehidupan makhluk hidup. Ironisnya dari waktu ke waktu, sumberdaya ini semakin mengkuatirkan keadaannya. Permasalahan air, baik itu dari segi jumlah maupun kualitasnya hampir selalu dihadapi di setiap wilayah.

Airtanah sebagai bagian dari sumberdaya air juga menghadapi permasalahan serupa. Ditinjau dari distribusinya di permukaan bumi, jumlah ketersediaan airtanah di suatu daerah tidak selalu sama. Ada daerah dengan potensi airtanah sangat besar, tetapi ada pula yang potensinya sangat kecil, tergantung dari besar kecilnya curah hujan, banyak sedikitnya vegetasi, kemiringan lereng serta derajat porositas dan permeabilitas batuan penyusunnya. Selain oleh faktor-faktor alami tersebut, besar kecilnya ketersediaan airtanah juga sangat tergantung dari laju pengambilannya, terutama untuk berbagai keperluan hidup manusia (Purnama 2006).

Daerah Aliran Sungai (DAS) Opak merupakan daerah dengan konsentrasi penduduk yang relatif tinggi di wilayah Daerah Istimewa Yogyakarta. Sungai Opak sebagai sungai utamanya bermataair di kaki Gunungapi Merapi dan mengalir melalui 
Kabupaten Sleman dan Kabupaten Bantul. Panjang sungai ini diperkirakan mencapai $65 \mathrm{~km}$. Ditinjau dari kondisi airtanahnya cukup bervariasi, ditunjukkan oleh perbedaan kedalaman muka air, karakteristik akuifer, debit jenis dan kualitas airnya. Variasi kondisi airtanah ini menyebabkan perbedaan pola pemanfaatan air di beberapa wilayah.

Airtanah tidak dijumpai di semua tempat. Keterdapatan airtanah tergantung dari ada tidaknya lapisan batuan yang dapat mengandung airtanah yang disebut akuifer. Akuifer adalah formasi batuan yang dapat menyimpan dan melalukan air, seperti misalnya pasir dan kerikil lepas (Seyhan 1977, Simoen 2001, Purnama 2004). Akuifer sering pula disebut waduk air atau formasi air. Formasi batuan yang merupakan kebalikan dari akuifer adalah akuifug, seperti misalnya granit. Akuifug merupakan formasi batuan yang tidak dapat menyimpan dan melalukan air (Fetter 1988).

Sifat batuan lain yang berhubungan dengan airtanah adalah akuiklud dan akuitard. Menurut Walton (1970), akuiklud adalah formasi batuan yang dapat menyimpan air tetapi tidak dapat melalukannya dalam jumlah yang berarti, misalnya liat, serpih, tuf halus dan batuan lain yang butirannya berukuran liat, sedangkan akuitard adalah formasi batuan dengan susunan sedemikian rupa, sehingga dapat menyimpan air, tetapi hanya dapat melalukannya dalam jumlah terbatas seperti misalnya pada rembesan atau kebocoran.

Ada berbagai formasi geologi yang dapat berfungsi sebagai akuifer. Formasi geologi tersebut adalah endapan aluvial, batu gamping, batuan vulkanik, batu pasir serta batuan beku dan batuan metamorfose
(Todd 1980). Sekitar 90\% airtanah terdapat pada endapan aluvial yang merupakan bahan lepas seperti pasir dan kerikil.

Ditinjau dari muka airtanahnya, akuifer dikelompokkan menjadi akuifer bebas dan akuifer tertekan (Bouwer 1978). Airtanah yang berasal dari akuifer bebas umumnya ditemukan pada kedalaman yang relatif dangkal, kurang dari 40 meter. Tinggi permukaan air dan kemiringannya bervariasi, sedangkan fluktuasi muka airtanah berhubungan erat dengan volume air dalam akuifer. Kasus khusus dari akuifer bebas adalah adanya akuifer menggantung (perched aquifer), yang terjadi akibat terpisahnya airtanah dari tubuh airtanah utama oleh suatu formasi batuan yang kedap air (Kodoatie 1996). Lensa-lensa liat pada batuan endapan seringkali membentuk akuifer menggantung.

Pada akuifer tertekan, airtanah terletak di bawah lapisan kedap air dan mempunyai tekanan lebih besar daripada tekanan udara. Akuifer jenis ini sering pula disebut akuifer artesis. Airtanah pada akuifer ini, di bagian atas ditekan oleh lapisan batuan kedap air, sehingga tekanannya melebihi tekanan atmosfir. Bila sumur menembus lapisan akuifer ini, airtanah akan naik melebihi lapisan penekannya atau bahkan muncul di permukaan tanah (Chorley 1969).

Disamping kedua jenis akuifer tersebut, ada pula yang disebut akuifer semi tertekan dan akuifer semi tidak tertekan yang merupakan kombinasi dari kedua jenis akuifer tersebut (Kruseman dan de Ridder 1970). Akuifer semi tertekan sering dijumpai di daerah lembah aluvial dan dataran, yang airtanahnya terletak di bawah lapisan yang setengah kedap. 
Selanjutnya, airtanah sebagai salah satu komponen dalam siklus hidrologi, akan mengalami perubahan komposisi kimia, baik berupa penambahan maupun pengurangan konsentrasi unsur kimia (Stauffer dan Canfield 1992). Adapun proses-proses yang dapat mempengaruhi perubahan komposisi kimia tersebut diantaranya adalah hujan, evaporasi dan transpirasi, pelarutan air fosil, pertukaran kation, pelarutan mineral, proses oksidasi-reduksi serta aktivitas manusia. Menurut Wagner, Shamir dan Nemati (1992) adanya airtanah asin di daratan merupakan salah satu bentuk pencemaran air, yang umumnya disebabkan oleh intrusi air laut. Aktivitas manusia merupakan penyebab utama fenomena ini, terutama akibat eksploitasi airtanah yang berlebihan, pembangunan permukiman yang sangat pesat di perkotaan, serta usaha tambak udang dan ikan di pantai. Meskipun demikian, faktor lingkungan alami juga dapat mempermudah terjadinya intrusi air laut, seperti karakteristik pantai dan batuan penyusun, kekuatan aliran airtanah ke laut dan fluktuasi airtanah di daerah pantai.

Berdasarkan latar belakang tersebut, maka tujuan penelitian ini adalah sebagai berikut :

1. Menentukan sistem akuifer di daerah penelitian

2. Menghitung potensi airtanah pada setiap satuan akuifer di daerah penelitian

\section{METODE PENELITIAN}

\section{Lokasi}

Lokasi penelitian di DAS Opak (tidak termasuk Sub DAS Oya), yang secara administratif berada di Daerah Istimewa Yogyakarta khususnya meliputi Kabupaten Sleman, Kabupaten Bantul dan Kota Yogyakarta. Ditinjau secara geomorfologi,
DAS Opak berada pada satuan Gunungapi Merapi dari puncak sampai dataran fluvial gunungapi. Bagian barat berbatasan dengan DAS Progo, di bagian timur laut berbatasan dengan DAS Bengawan Solo dan di bagian tenggara berbatasan dengan sistem sungai di daerah karst Gunung Kidul.

DAS Opak secara keseluruhan mempunyai luas $1398 \mathrm{~km}^{2}$. Karena dalam penelitian ini tidak meliputi Sub DAS Oya, maka luas daerah penelitian adalah 665,12 $\mathrm{km}^{2}$.

\section{Perhitungan Potensi Airtanah}

Potensi airtanah dalam penelitian ini adalah jumlah airtanah yang tersedia per kapita dalam angka rata-rata tahunan. Ketersediaan airtanah diperhitungkan dengan dua pendekatan :

\section{1) Pendekatan statis}

Perhitungan volume airtanah metode statis menggunakan rumus :

Vat $=$ Sy x Vak

dengan Vat adalah volume airtanah yang dapat lepas dari akuifer, Sy adalah specific yield atau persentase air yang dapat lepas dari akuifer (ditentukan menggunakan tabel Sy berdasarkan jenis material batuan penyusun akuifer dari data sumur bor) dan Vak adalah volume akuifer (luas penampang akuifer dikalikan dengan tebal akuifer).

2) Pendekatan dinamis

Airtanah dalam akuifer berasal dari air infiltrasi dan aliran airtanah dari akuifer di bagian hulu. Konsep neraca airtanah tahunan ditunjukkan pada Gambar 1 berikut: dengan Qo adalah aliran airtanah yang keluar dari akuifer, Qi adalah aliran airtanah 


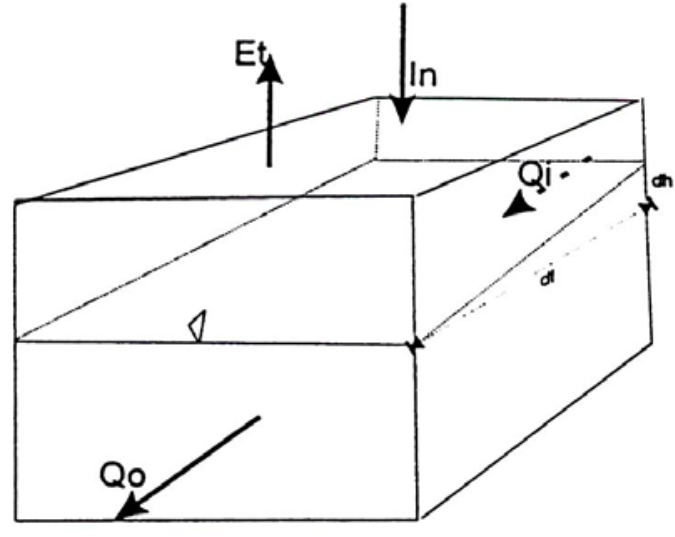

Gambar 1. Konsep Neraca Air Tahunan

yang masuk ke akuifer, In adalah air yang masuk melalui infiltrasi dan Et adalah air yang keluar melalui evapotranspirasi. Selanjutnya debit airtanah dapat dihitung dengan rumus Darcy (Fetter, 1994) :

$\mathrm{Q}=\mathrm{KAdh} / \mathrm{dl}$

dengan Q adalah debit atau jumlah aliran airtanah, $\mathrm{K}$ adalah permeabilitas akuifer, A adalah luas penampang akuifer dan dh/ dl adalah gradien hidrolik atau kemiringan permukaan airtanah.

\section{HASIL PENELITIAN DAN PEM- BAHASAN}

\section{Hidrologi dan Geologi}

Sungai Opak berhulu di Gunungapi Merapi dan Pegunungan Baturagung. Potensi sungai ini cukup besar dan merupakan sungai kedua terbesar di Propinsi Daerah Istimewa Yogyakarta. Sungai Opak mempunyai sembilan percabangan sungai yaitu Oya, Winongo, Code, Gajahwong, Pesing, Tambakbayan, Kuning, Ngijo dan Tepus.

Sungai Opak dan anak-anak sungainya tersebut mengalir melalui empat satuan geologi, yaitu Endapan Volkanik Merapi Muda, Endapan Aluvium, Formasi Semilir dan Formasi Nglanggran. Endapan Volkanik Merapi Muda menempati hampir 90\% daerah penelitian, membentang dari hulu di lereng atas Gunungapi Merapi hingga mendekati muara di pantai Parangtritis. Endapan ini terdiri atas tuf, abu volkanik, breksi volkanik, aglomerat dan lelehan lava. Lapukan dari Endapan Volkanik Merapi Muda membentuk dataran kaki dan dataran fluvio volkanik yang terkerjakan ulang oleh alur-alur sungai. Endapan Volkanik Merapi Muda inilah yang merupakan akuifer utama di DAS Opak.

Endapan Aluvium hanya menempati daerah yang sempit, yaitu di dekat muara Sungai Opak serta di kanan-kiri sungai. Endapan ini tersusun dari kerakal, pasir, lanau dan lempung. Formasi Semilir menempati escarpment Pegunungan Baturagung yang membentang dari Prambanan hingga pantai Parangtritis. Litologi yang menyusun formasi ini adalah perselingan antara breksi tuf, breksi batuapung, tuf dasit dan tuf andesit serta batulempung bertufa. Satuan geologi yang keempat yaitu Formasi Nglanggran, berada di atas Formasi Semilir. Formasi ini menempati igir-igir bagian atas dari escarpment, yang tersusun dari breksi volkanik, breksi aliran, aglomerat, lava dan tuf. Sebagian besar lapisan ini telah melapuk menjadi tanah berwarna coklat kemerahan.

\section{Sistem Akuifer DAS Opak}

Berdasarkan kondisi geologi dan geomorfologinya, sistem akuifer di DAS Opak dapat dibedakan menjadi tujuh satuan utama yaitu Satuan Akuifer Merapi I (Satuan Akuifer Volkan Merapi Bagian Atas), Satuan Akuifer Merapi II (Satuan Akuifer Volkan Merapi Bagian Tengah), 
Satuan Akuifer Merapi III (Satuan Akuifer Volkan Merapi Bagian Bawah atau Satuan Akuifer Dataran Fluvio Volkanik Merapi), Satuan Akuifer Lereng Kaki Perbukitan Baturagung, Satuan Akuifer Perbukitan Baturagung, Satuan Akuifer Perbukitan Sentolo dan Satuan Akuifer Gumuk Pasir (Gambar 2). Berikut ini disampaikan karakteristik ketujuh satuan akuifer ini.

\section{Satuan Akuifer Merapi I (Satuan Akuifer Volkan Merapi Bagian Atas)}

Satuan Akuifer Volkan Merapi Bagian Atas berada pada lereng volkan Merapi, mulai dari puncak Gunungapi Merapi hingga jalur Pakem-Cangkringan. Material penyusunnya berupa endapan lahar yang lepas dengan material pasir, kerakal dan boulder, sedangkan di bawahnya dialasi oleh aliran lava. Infiltrasi dan hujan di daerah ini sangat besar, sehingga merupakan daerah imbuh airtanah yang potensial. Airtanah di daerah ini sangat dalam dan jarang dijumpai sumur gali. Kebutuhan air domestik untuk penduduk dicukupi dengan air dari mataair yang muncul di Jalur KaliurangBebeng. Ditinjau dari produktivitasnya, sistem akuifer ini tidak produktif karena kurang mampu menyimpan air. Air yang terinfiltrasi di daerah ini terus mengalir masuk ke Satuan Akuifer Volkan Merapi bagian tengah.

\section{Satuan Akuifer Merapi II (Satuan Akuifer Volkan Merapi Bagian Tengah)}

Satuan akuifer ini berada pada lereng kaki gunungapi dan dataran fluvial kaki gunungapi. Daerah sebarannya mulai dari jalur Pakem-Cangkringan ke selatan sampai Prambanan, Kalasan dan Yogyakarta. Material utamanya adalah pasir dan kerakal dengan ketebalan akuifer mencapai 100 meter atau lebih, ditunjukkan oleh material pada beberapa sumur bor dimana hingga kedalaman 100 meter masih berupa material pasir yang bersifat andesitis. Dasar dari akuifer ini berupa aliran lava volkan Merapi. Adanya jalur-jalur mataair yang membentuk sabuk mataair pada perubahan lereng merupakan ciri dari satuan akuifer ini.

Satuan Akuifer Volkan Merapi Bagian Tengah merupakan akuifer dengan sebaran airtanah luas dengan imbuh airtanah berasal dari lereng gunungapi dan infiltrasi setempat. Memperhatikan daerah imbuh airtanah, material penyusun akuifer dan curah hujannya, akuifer ini dikategorikan sebagai akuifer mayor, yaitu sistem akuifer yang mampu menyediakan air untuk berbagai keperluan, seperti untuk keperluan domestik, industri dan irigasi.

Ditinjau dari karakteristik akuifernya, permeabilitas dari akuifer ini tergolong dalam kriteria cepat. Hasil perhitungan berdasarkan data dari delapan sumur bor yang ada (Cupuwatu 1, Cupuwatu 2, Tamanmartani, Krendosari, Klampengan, Berbah, Candirejo dan Hotel Santika), menunjukkan bahwa nilai rata-rata permeabilitas akuifernya mencapai 115,1 $\mathrm{m} /$ hari, dengan transmisibilitas akuifer dan debit jenis mencapai $841,9 \mathrm{~m}^{2} /$ hari dan $3,79 \mathrm{~m}^{3} / \mathrm{det} / \mathrm{m}$.

\section{Satuan Akuifer Merapi III (Satuan Akuifer Dataran Fluvio Volkanik Merapi)}

Satuan Akuifer Dataran Fluvio Volkanik Merapi atau Satuan Akuifer Volkan Merapi Bagian Bawah terhampar dari Kalasan dan Yogyakarta ke arah selatan hingga mendekati gumuk pasir. Sebagian besar material penyusunnya berupa pasir dan lempung sebagai sisipansisipan. Dari arah barat ke timur, akuifer mempunyai ketebalan maksimum di bagian 


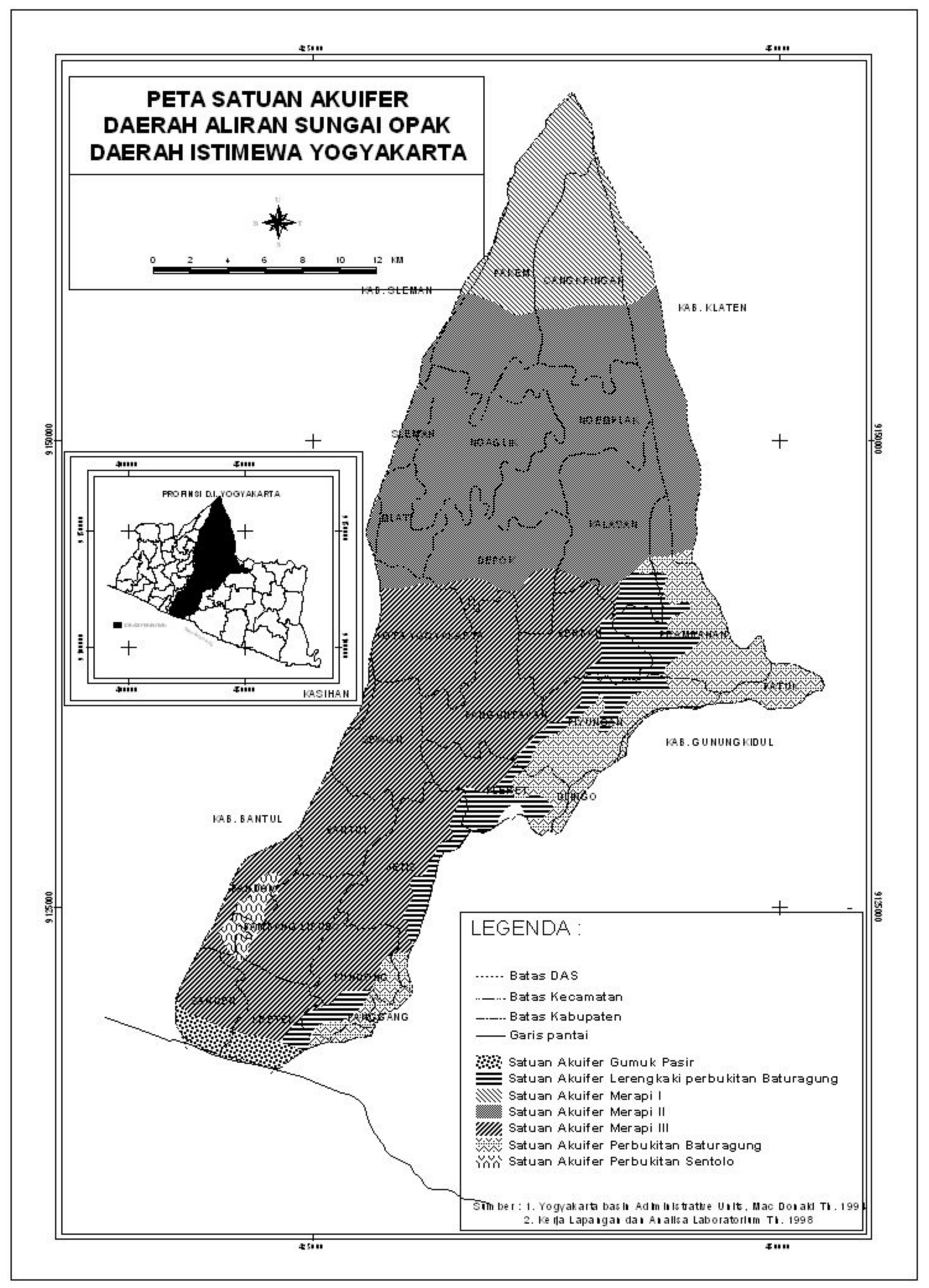

Gambar 2. Sistem Akuifer Daerah Aliran Sungai Opak 
tengah dan semakin menipis ke arah perbukitan Baturagung di bagian timur dan perbukitan Sentolo di sebelah barat. Batuan dasar yang mengalasi sistem akuifer ini adalah batugamping dan napal dari Formasi Sentolo.

\section{Satuan Akuifer Dataran Fluvio} Volkanik Merapi merupakan akuifer mayor, yaitu akuifer yang mampu menyediakan air untuk keperluan domestik dan industri. Imbuh airtanah akuifer ini berasal dari aliraan airtanah dari satuan akuifer Volkan Merapi bagian tengah dan imbuh lokal dari infiltrasi air hujan.

Ditinjau dari karakteristik akuifernya, permeabilitas dari akuifer ini tergolong dalam kriteria cepat. Hasil perhitungan berdasarkan data dari sepuluh sumur bor yang ada (Dongkelan, Jambi, Batikan, Manding, Barongan, Mulyodadi, Giren, Sumbermulyo, Tamprit dan Celep), menunjukkan bahwa nilai rata-rata permeabilitas akuifernya mencapai 59,9 m/hari, dengan transmisibilitas akuifer dan debit jenis mencapai $921,9 \mathrm{~m}^{2} /$ hari dan $4,00 \mathrm{~m}^{3} / \mathrm{det} / \mathrm{m}$.

\section{Satuan Akuifer Perbukitan Baturagung dan Lereng Kakinya}

Sebenarnya agak sulit untuk menentukan nilai permeabilitas dan transmisibilitas akuifer di Satuan Akuifer Perbukitan Baturagung. Berdasarkan kondisi batuannya, MacDonald (1984) menyatakan bahwa Perbukitan Baturagung bukan merupakan akuifer dan merupakan daerah langka airtanah.

Di bagian lereng kaki bagian barat materialnya berupa endapan koluvium. Memperhatikan daerah imbuh dan materialnya, daerah ini termasuk akuifer minor yaitu akuifer yang cukup mampu untuk menyediakan air bagi keperluan domestik dan penyiraman tanaman secara tradisional.

Ditinjau dari karakteristik akuifernya, permeabilitas dari akuifer ini tergolong dalam kriteria sedang. Hasilperhitungan berdasarkan data dari dua sumur bor yang ada (Pelemadu dan Mutihan), menunjukkan bahwa nilai rata-rata permeabilitas akuifernya hanya mencapai $1,72 \mathrm{~m} /$ hari, dengan transmisibilitas akuifer dan debit jenis sebesar $12,55 \mathrm{~m}^{2} /$ hari dan $0,30 \mathrm{~m}^{3} / \mathrm{det} / \mathrm{m}$.

\section{Satuan Akuifer Perbukitan Sentolo}

Satuan Akuifer Perbukitan Sentolo hanya meliputi sebagian kecil dari DAS Opak. Satuan ini terdapat di sebelah barat Bambanglipuro yaitu di daerah Pandak dengan relief bergelombang. Satuan akuifer ini merupakan bagian dari Perbukitan Sentolo yang terpisahkan oleh endapan aluvium. Material penyusun sistem ini berupa batugamping dan napal yang padu/ kompak, sedangkan material lepas hasil lapukan dijumpai sangat tipis di permukaannya sehingga diperkirakan daerah ini termasuk akuifer yang tidak produktif. MacDonald (1984) mengklasifikasikannya sebagai akuifer minor yaitu akuifer yang hanya mampu menyediakan air untuk keperluan domestik.

\section{Satuan Akuifer Gumuk Pasir}

Satuan Akuifer Gumuk Pasir terdapat di sekitar muara Sungai Opak, terhampar di sepanjang pantai dengan lebar antara 3 dan $4 \mathrm{~km}$. Satuan ini dicirikan oleh perselingan antara beting gisik (beach ridge) dan swale, dengan material pada cekungan (swale) relatif lebih halus daripada di beting gisik. Ditinjau dari material penyusunnya, berupa pasir lepas dari Gunungapi Merapi yang terbawa Sungai Opak serta oleh penghempasan gelombang laut dan angin. 
Dari data bor, diketahui ketebalan satuan akuifer ini antara 20 dan 45 meter dan semakin ke utara semakin tipis membentuk struktur baji. Batuan dasar yang mengalasi satuan ini adalah lempung endapan marin.

Ditinjau dari karakteristik akuifernya, permeabilitas dari akuifer ini tergolong dalam kriteria cepat. Hasil perhitungan berdasarkan data dari dua sumur bor yang ada (Samas 1 dan Samas 2), menunjukkan bahwa nilai rata-rata permeabilitas akuifernya mencapai $57,2 \mathrm{~m} /$ hari, dengan transmisibilitas akuifer dan debit jenis sebesar $286 \mathrm{~m}^{2} /$ hari dan $2,86 \mathrm{~m}^{3} /$ hari $/ \mathrm{m}$.

\section{Kedalaman dan Fluktuasi Airtanah}

Kedalaman airtanah yang dalam hal ini adalah kedalaman muka freatik di DAS Opak cukup bervariasi. Meskipun demikian, secara umum semakin ke selatan atau ke arah laut kedalamannya semakin dangkal. Pada Satuan Akuifer Merapi I dan II (Satuan Akuifer Volkan Merapi Bagian Atas dan Tengah), kedalaman airtanah berkisar antara 5,7 hingga 13,9 meter dari permukaan tanah, dengan fluktuasi airtanah berkisar antara 0,3 hingga 4 meter. Hal yang perlu diperhatikan dalam kaitannya dengan kondisi airtanah pada Satuan Akuifer Merapi I dan II ini adalah adanya pemunculan airtanah sebagai sumber air di setiap perubahan lereng. Fenomena ini ditunjukkan oleh kedalaman sumur di zone tersebut yang hanya mencapai 0,2 hingga 4 meter permukaan tanah.

Kondisi airtanah yang cukup baik juga didapatkan pada Satuan Akuifer Merapi III (Satuan Akuifer Dataran Fluvio Volkanik Merapi) dan Satuan Akuifer Gumuk Pasir. Jika pada Satuan Akuifer Merapi I dan II meliputi wilayah Kabupaten Sleman, maka Satuan Akuifer III meliputi
Kota Yogyakarta dan sebagian besar Kabupaten Bantul. Kedalaman airtanah berkisar antara 0,5 hingga 5,3 meter dari permukaan tanah, dengan fluktuasi air antara 0,4 hingga 4,6 meter, sedangkan pada Satuan Akuifer Gumuk Pasir, kedalaman airtanahnya berkisar antara 1,8 hingga 4,2 meter dari permukaan tanah.

Pada Satuan Akuifer Perbukitan Sentolo dan Pegunungan Baturagung, muka airtanahnya terletak cukup dalam, bahkan pada tempat-tempat tertentu tidak dijumpai adanya airtanah. Jika pada Formasi Sentolo batuan yang dominan adalah batugamping dan napal, maka pada Satuan Akuifer Pegunungan Baturagung batuannya adalah breksi dan tuf. Kecuali batugamping, jenis-jenis batuan tersebut merupakan batuan yang kedap air atau tidak dapat menyimpan air.

\section{Potensi Airtanah DAS Opak}

Seperti telah dijelaskan pada sub bab kedalaman dan fluktuasi airtanah, kedalaman muka airtanah (muka freatik) di DAS Opak secara umum semakin ke arah selatan atau ke arah laut semakin dangkal. Di Satuan Akuifer Merapi I dan II, kedalaman muka airtanah berkisar antara 5,7 dan 13,9 meter dari permukaan tanah. Fenomena yang perlu diperhatikan mengenai kondisi airtanah di satuan akuifer ini (khususnya Satuan Akuifer Merapi II) adalah pemunculan airtanah sebagai sumber mataair pada setiap perubahan lereng, dibuktikan adanya beberapa sumur yang kedalamannya hanya mencapai 0,2 hingga 4 meter. Selanjutnya ketersediaan airtanah secara statis masing-masing satuan akuifer diperhitungkan sebagai berikut (Tabel 2).

Volume airtanah di DAS Opak diperhitungkan sebesar 9.370,6 juta m Airtanah sebanyak itu tidak semuanya 
Tabel 2. Perhitungan Potensi Airtanah dengan Pendekatan Statis

\begin{tabular}{|l|l|c|c|c|c|c|}
\hline No. & \multicolumn{1}{|c|}{ SATUAN AKUIFER } & $\begin{array}{c}\mathrm{A} \\
\left(\mathrm{km}^{2}\right)\end{array}$ & $\begin{array}{c}\mathrm{D} \\
(\mathrm{m})\end{array}$ & $\begin{array}{c}\text { Vak } \\
\left(\mathrm{juta}^{3}\right)\end{array}$ & \multicolumn{1}{c|}{ Sy } & $\begin{array}{c}\text { Vat } \\
\left(\text { juta } \mathrm{m}^{3}\right)\end{array}$ \\
\hline 1. & Volkan Merapi Bagian Atas & 78 & - & - & - & - \\
\hline 2. & Volkan Merapi Bagian Tengah & 169 & 70 & 11830 & 0,32 & $3.785,6$ \\
\hline 3. & Dataran Fluvio Volkanik Merapi & 253,5 & 65 & $\begin{array}{c}16.477, \\
5\end{array}$ & 0,32 & $5.272,8$ \\
\hline 4. & Pegunungan Baturagung & 67 & - & - & - & - \\
\hline 5. & Lereng Kaki Pegunungan Baturagung & 41 & 20 & 820 & 0,20 & 164 \\
\hline 6. & Perbukitan Sentolo & 3 & 3 & - & 0,14 & - \\
\hline 7. & Gumuk Pasir & 9,75 & 40 & 390 & 0,38 & 148,2 \\
\hline & & & & Jumlah & $9.370,6$ \\
\hline
\end{tabular}

Sumber : hasil perhitungan

Keterangan :
A $=$ luas akuifer $\left(\mathrm{km}^{2}\right)$
Sy $\quad=$ spesifik yield
$\mathrm{D}=$ tebal akuifer
Vat = volume airtanah
Vak = volume akuifer $\left(\right.$ juta $\mathrm{m}^{3}$ )

Tabel 3. Perhitungan Hasil Aman Ketersediaan Airtanah Secara Statis

\begin{tabular}{|c|l|c|c|c|c|c|c|}
\hline No. & \multicolumn{1}{|c|}{ SATUAN AKUIFER } & $\begin{array}{c}\mathrm{A} \\
\left(\mathrm{km}^{2}\right)\end{array}$ & $\begin{array}{c}\mathrm{F} \\
(\mathrm{m})\end{array}$ & $\begin{array}{c}\text { Vak } \\
\left(\mathrm{juta} \mathrm{m}^{3}\right)\end{array}$ & Sy & $\begin{array}{c}\text { Vata } \\
\left(\text { juta }^{3}\right)\end{array}$ & $\begin{array}{c}\text { Vata } \\
\left(\mathrm{juta}^{3} /\right. \\
\left.\mathrm{km}^{2} / \mathrm{th}\right)\end{array}$ \\
\hline 1. & Volkan Merapi Bagian Atas & 78 & - & - & - & - & - \\
\hline 2. & Volkan Merapi Bagian Tengah & 169 & 6 & 1014 & 0,32 & 324,48 & 1,92 \\
\hline 3. & Dataran Fluvio Volkanik Merapi & 253,5 & 2 & 507 & 0,32 & 162,24 & 0,64 \\
\hline 4. & Pegunungan Baturagung & 67 & - & - & - & - & - \\
\hline 5. & $\begin{array}{l}\text { Lereng Kaki Pegunungan } \\
\text { Baturagung }\end{array}$ & 41 & 2 & 82 & 0,20 & 16,4 & 0,40 \\
\hline 6. & Perbukitan Sentolo & 3 & 10 & 30 & 0,14 & 4,2 & 1,4 \\
\hline 7. & Gumuk Pasir & 9,75 & 2 & 19,5 & 0,38 & 7,41 & 0,76 \\
\hline
\end{tabular}

Sumber : hasil perhitungan 
sebagai airtanah tersedia. Ketersediaan airtanah yang dapat diambil untuk berbagai pemanfaaatan harus mempertimbangkan bahaya kekeringan dan overdraft. Oleh karena itu, airtanah tersedia dihitung sebatas fluktuasi muka airtanah tahunan seperti ditunjukkan pada Tabel 3.

Memperhatikan Tabel 2 dan 3, terlihat bahwa akuifer yang paling potensial adalah satuan akuifer Merapi II atau akuifer Merapi bagian tengah yaitu kawasan antara jalur Pakem-Cangkringan dengan GampingPrambanan. Kenyataan ini didukung juga dengan data permeabilitas dan transmisibilitas akuifernya yang mencapai 115,1 $\mathrm{m} /$ hari dan $841 \mathrm{~m}^{2} /$ hari.

Perhitungan potensi airtanah secara statis tidak memperhitungan adanya aliran airtanah di dalam DAS dan dari daerah lain di sekitarnya. Untuk itu, dalam Tabel 4 berikut ini ditunjukkan hasil perhitungan potensi airtanah secara dinamis di daerah penelitian.
Dari hasil perhitungan pada Tabel 4 tersebut, terlihat bahwa Satuan Akuifer Volkan Merapi Bagian Tengah juga merupakan satuan akuifer di DAS Opak yang mempunyai potensi tertinggi yaitu sebesar $1.041 \mathrm{~m}^{3} /$ hari $/ \mathrm{km}^{2}$. Disusul kemudian oleh Dataran Fluvio Volkanik Merapi dan Satuan Akuifer Gumuk pasir. Dalam perhitungan potensi airtanah secara dinamis, Satuan Akuifer Pegunungan Baturagung, Lereng Kaki Pegunungan Baturagung dan Perbukitan Sentolo tidak ikut diperhitungkan karena tidak adanya sistem aliran airtanah di ketiga daerah tersebut.

\section{KESIMPULAN}

1) Berdasarkan kondisi geologi dan geomorfologinya, sistem akuifer yang ada di DAS Opak dapat dibedakan menjadi tujuh satuan akuifer, yaitu Satuan Akuifer Volkan Merapi Bagian Atas, Satuan Akuifer Volkan Merapi Bagian Tengah, Satuan Akuifer Merapi

Tabel 4. Perhitungan Potensi Airtanah dengan Pendekatan Dinamis

\begin{tabular}{|l|c|c|c|c|c|c|c|}
\hline Satuan Akuifer & $\begin{array}{c}\text { Surplus } \\
(\mathrm{mm} / \mathrm{th})\end{array}$ & $\begin{array}{c}\text { Koefisien } \\
\text { Limpasan } \\
(\%)\end{array}$ & $\begin{array}{c}\text { Infiltrasi } \\
(\mathrm{mm} / \mathrm{th})\end{array}$ & $\begin{array}{c}\text { Debit } \\
\text { Inflow } \\
\left(\mathrm{m}^{3} / \mathrm{hari}\right)\end{array}$ & $\begin{array}{c}\text { Debit } \\
\text { Outflow } \\
\left(\mathrm{m}^{3} / \mathrm{hari}\right)\end{array}$ & $\begin{array}{c}\Delta \text { St } \\
\left(\mathrm{m}^{3} / \mathrm{hari}\right)\end{array}$ & $\begin{array}{c}\text { Potensi } \\
\text { Airtanah } \\
\left(\mathrm{m}^{3} / \mathrm{hari}^{2} \mathrm{~km}^{2}\right)\end{array}$ \\
\hline $\begin{array}{l}\text { Volkan Merapi } \\
\text { Bagian Atas }\end{array}$ & 1.720 & 25 & 1.290 & - & 32.250 & - & - \\
$\begin{array}{l}\text { Volkan Merapi } \\
\text { Bagian Tengah }\end{array}$ & 937 & 70 & 281 & 322.500 & 69.248 & 253.252 & 1.041 \\
$\begin{array}{l}\text { Dataran Fluvio } \\
\text { Volkanik Merapi }\end{array}$ & 481 & 60 & 192 & 693 & 1.992 & 61.250 & 681 \\
Gumuk Pasir & 211 & 10 & 190 & 7.992 & 5.720 & 2.722 & 194 \\
\hline
\end{tabular}

Sumber : hasil perhitungan 
Bagian Bawah (Dataran Fluvio Volkanik Merapi), Satuan Akuifer Pegunungan Baturagung, Satuan Akuifer Lereng Pegunungan Baturagung, Satuan Akuifer Perbukitan Sentolo dan Satuan Akuifer Gumuk Pasir.

2) Akuifer yang mempunyai produktivitas tinggi adalah Satuan Akuifer Merapi Bagian Tengah (1,92 juta $\left.\mathrm{m}^{3} / \mathrm{km}^{2} / \mathrm{th}\right)$, Satuan Merapi Bagian Bawah (0,64 juta $\left.\mathrm{m}^{3} / \mathrm{km}^{2} / \mathrm{th}\right)$ dan Satuan Akuifer Gumuk Pasir (0,76 juta $\left.\mathrm{m}^{3} / \mathrm{km}^{2} / \mathrm{th}\right)$. Akuifer yang kurang produktif meliputi Satuan Akuifer Perbukitan Sentolo (1,4 juta $\mathrm{m}^{3} / \mathrm{km}^{2} / \mathrm{th}$ ) dan Satuan Akuifer Lereng
Kaki Pegunungan Baturagung (0,40 juta $\left.\mathrm{m}^{3} / \mathrm{km}^{2} / \mathrm{th}\right)$, sedangkan Satuan Akuifer Pegunungan Baturagung merupakan daerah yang langka airtanah.

\section{UCAPAN TERIMA KASIH}

Tulisan ini merupakan bagian dari penelitian yang berjudul "Survei Pemanfaatan dan Konservasi Airtanah di Daerah Pengaliran Sungai Opak”. Ucapan terima kasih disampaikan kepada Drs. Eko Haryono, M.Si dan Dra. M. Widyastuti, M.T atas kontribusinya sebagai anggota dalam penelitian ini.

\section{DAFTAR PUSTAKA}

Bouwer, H. 1978. Groundwater Hydrology. McGraw-Hill Book Company, New York.

Chorley. 1969. Introduction to Physical Hydrology. Barnes and Noble Inc, New York.

Fetter, C. W. 1988. Applied Hydrogeology. Macmillan Publishing Company, New York.

Kodoatie, R. J. 1996. Pengantar Hidrogeologi. Penerbit Andi, Yogyakarta.

Kruseman, G. P and N. A. de Ridder. 1970. Analysis and Evaluation of Pumping Test Data. International Institute for Land Reclamation and Improvement, Wageningen.

MacDonald and Partners. 1984. Greater Yogyakarta, Groundwater Resources Study Volume III : Groundwater. Overseas Development Administration, London, Directorate General of Water Development. Groundwater Development Project (P2AT) Indonesia.

Purnama, S. 2004. Infiltrasi tanah di Kecamatan Nguter, Kabupaten Sukoharjo, Propinsi Jawa Tengah. Majalah Geografi Indonesia 18 (1) : 1-14.

Purnama, S. 2006. "Model konservasi airtanah di Dataran Pantai Kota Semarang". Forum Geografi, Vol. 20, No. 2, Desember 2006. Hlm 160-174.

Seyhan, E. 1977. Fundamentals of Hydrology. Geografisch Instituut der Rijks-universiteit te Utrecht, Utrecht.

Simoen, S. 2001. Sistem akuifer di lereng Gunungapi Merapi bagian timur dan tenggara : studi kasus di kompleks Mataair Sungsang Boyolali Jawa Tengah. Majalah Geografi Indonesia 15 (1) : 141-152. 
Stauffer, R. E and D. E. Canfield. 1992. Hydrology and alkalinity regulation of soft flourida waters : an integrated asessment. Water Resources Research 28 (6) : 1901- 1923.

Todd, D. K. 1980. Groundwater Hydrology. John Wiley \& Sons, New York.

Wagner, J. M., U. Shamir and H. R.Nemati. 1992. Groundwater quality management under urcertainty : stochastic programming approach and the value of Information. Water Resources Research 28 (5) : 1511-1530.

Walton, W.C. 1970. Groundwater Resources Evaluation. John Wiley and Sons Inc., New York.

Widyastuti, M. dan Slamet Suprayogi. 2006. "Contamination Vulnerability Analysis of Watershed for Water Quality Monitoring”. Forum Geografi, Vol. 20, No. 1, Juli 2006. Hlm 47-54. 